\title{
Technological study of the gilded haft-rang tiles of the Imamzadih Ismail mausoleum in Qazvin, Iran
}

\author{
Moslem Mishmastnehi $^{{ }^{*}}$ and Parviz Holakooei ${ }^{2}$
}

\begin{abstract}
Background: Gilding decorations on Islamic tiles have been previously studied either historically or technologically. The major emphasis in these studies has always been focused on the use of gold leaf on glazed tiles. The current research has been conducted by electron probe micro-analysis (EPMA), portable micro X-ray fluorescence ( $\mu$-XRF), scanning electron microscopy (SEM), optical microscopy and atomic force microscopy (AFM) to shed light on a less-known technique of gilding applied on the nineteenth century haft rang glazed tiles of the Imamzadih Ismail mausoleum in Qazvin, Iran.
\end{abstract}

Results: Our observations showed that the gilding decorations are performed on a blue alkali glaze. Plant ash was suggested to be the source of alkali and cobalt was identified as the colouring agent of the glaze. Moreover, trace amounts of arsenic in the composition of the blue glaze was interpreted to be associated with the colouring agent of the glaze; i.e., cobalt. Furthermore, the gilding decorations were suggested to be achieved by firing gold powder on the pre-fired blue substrate glaze. AFM, SEM and optical microscopy proved that the gold flakes partially penetrated the pre-fired blue substrate glaze.

Conclusions: This paper established a local provenance for the colouring agent of the blue glaze used as a substrate of gilding decorations. In addition, our studies showed that the gilding decorations were achieved by firing gold powder on the pre-fired blue glaze of a nineteenth century Persian haft rang tile.

\section{Background}

The use of gold leaf on silica-based substrates may be dated back to the Roman period [1]. In the Islamic era, however, gilding on glassy substrates appears first on tableware in 12th century Persia [2] and shortly after on glassware under the Ayyubids and the Mamluks in Syria and Egypt during the 13th and 14th centuries [3].

Although the use of gold powder for gilding vitreous materials has been reported previously [3,4], technical literature about Islamic gilded tiles does not support this idea. In other words, the published data about gilding on the Islamic glazes are only limited to the use of gold leaf on glazes $[2,5,6]$. In addition, there is no general consensus about the technique of applying either gold leaf or powder on archaeological glazes. While the

\footnotetext{
* Correspondence: mmishmast@zedat.fu-berlin.de

${ }^{1}$ Institute for Near Eastern Archaeology, Freie Universität Berlin, Hüttenweg 7, 14195 Berlin, Germany

Full list of author information is available at the end of the article
}

use of an organic adhesive as mordant of gold leaf has already been reported [5,6], a firing process has also been suggested to be the reason of adhering gold leaf on a pre-fired glaze [2]. In support of the former idea, there is the Abu'l Qasim's treatise in which he describes how to fire gold leafs on a pre-fired glassy surface $[7,8]$.

Here, in this paper, various analytical approaches are used to address technological features of a less-known technique of gilding applied on a glassy substrate found in the Imamzadih Ismail mausoleum of Qazvin, Iran, erected in the 19th century. To do so, tiny samples were removed from a gilded haft rang tile in the south-eastern portico of the mausoleum (for more details see the Samples sub-section in the Methods section) (Figure 1) and were studied by electron probe micro-analysis (EPMA), portable micro X-ray fluorescence ( $\mu$-XRF), scanning electron microscopy (SEM) and atomic force microscopy (AFM).

\section{Chemistry Central}

(c) 2015 Mishmastnehi and Holakooei; licensee Springer. This is an Open Access article distributed under the terms of the Creative Commons Attribution License (http://creativecommons.org/licenses/by/4.0), which permits unrestricted use, distribution, and reproduction in any medium, provided the original work is properly credited. The Creative Commons Public Domain Dedication waiver (http://creativecommons.org/publicdomain/zero/1.0/) applies to the data made available in this article, unless otherwise stated. 


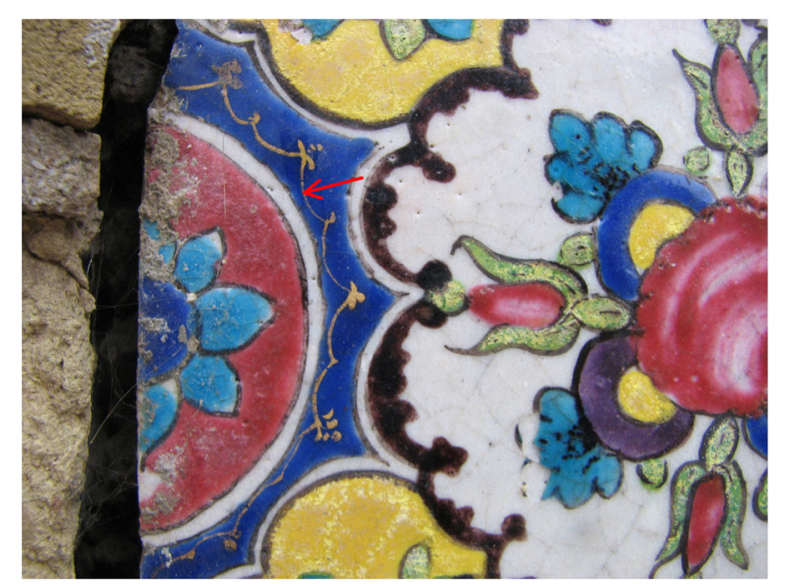

Figure 1 Detail of gilding decorations in a gilded haft rang tile at the Imamzadih Ismail mausoleum (the gilded line is pointed with a red arrow).

\section{Results and discussion}

Chemical composition of the substrate glaze

Under a closer look, it could be observed that the gold layer was placed on a blue glaze (Figure 1a), which was applied on a white glaze (Figure $2 \mathrm{~b}$ ). This stratigraphy demonstrates the usual structure of haft rang tiles [9]. The chemical composition of the white glaze (Table 1) showed that it was basically a lead-alkali tin-opacified glaze with a $\mathrm{Pb} / \mathrm{Sn}$ ratio of 7.3 , which is significantly higher than the $\mathrm{Pb} / \mathrm{Sn}$ ratio reported for 17 th century Persian haft rang tiles [9] and medieval Islamic glazes [10]. This value is also higher than the $\mathrm{Pb} / \mathrm{Sn}$ ratio documented in medieval Persian treatises of glaze-making $[7,11]$.

As far as the chemical composition of the blue glaze is concerned, it was an alkali glaze in which cobalt had yielded a dark blue colour (Table 1). On the other hand, $4.29 \mathrm{wt} \%$ and $0.37 \mathrm{wt} \%$ of potassium and magnesium respectively showed that the source of alkali in the blue glaze was most probably plant ash. Plant ash has been reported to be the most common fluxing agent used in Persian archaeological vitreous materials $[12,13]$. More interestingly, the chemical composition of the blue glaze was interestingly associated with arsenic (Table 1). As it is generally well-known, the cobalt ores of Qamsar, near Kashsn in central Iran, have always been noted to be the source of supplying cobalt for achieving deep blue colours in glassy materials. These ores have been reported to be cobaltite (CoAsS) and erythrite $\left(\mathrm{Co}_{3}\left(\mathrm{AsO}_{4}\right)\right.$ $2 \cdot 8 \mathrm{H}_{2} \mathrm{O}$ ), which are As-bearing cobalt ores $[7,14]$. Thus, the detected arsenic in the composition of the blue glaze can be derived from these sources showing a Persian provenance for the blue colouring agent of the glaze. On the other hand, the absence of bismuth in the composition of the blue glaze can be considered as another evidence of the local provenance as bismuth is reported to be associated with the blue Co-bearing pigments found in Europe and India [15].

Another interesting point in the quantitative EPMA data is that the actual total of the quantified elements of the blue glaze does not sum up to $100 \mathrm{wt} \%$ and is significantly low (86.26 wt\%) (Table 1$)$. This could be related to the manufacturing process of the blue glaze. According to the descriptions provided by Rochechouart [16], Ali Mohamed [11], Olmer [17] and Schindler [18], 19th century Persian glaze-makers used to make a concentrated Co-bearing pigment from the cobalt ores of Qamsar by mixing and smelting the cobalt ores and borax. A tiny amount of this concentrated pigment was then added to an alkali frit to achieve a deep blue colour. Moreover, the analytical data provided on the raw materials used by Ali Mohamed (preserved at the Edinburg $\mathrm{Mu}$ seum of Science) confirm the presence of borax in the composition of Persian blue glazes in the 19th century [18]. However, as boron cannot be measured with EPMA due to its low atomic weight, this can provide an explanation for the loss of total amount of composing elements of the blue glaze. However, this hypothesis needs to be proved with more relevant analytical approaches. Due to the fact that the blue glaze was diffused in the white
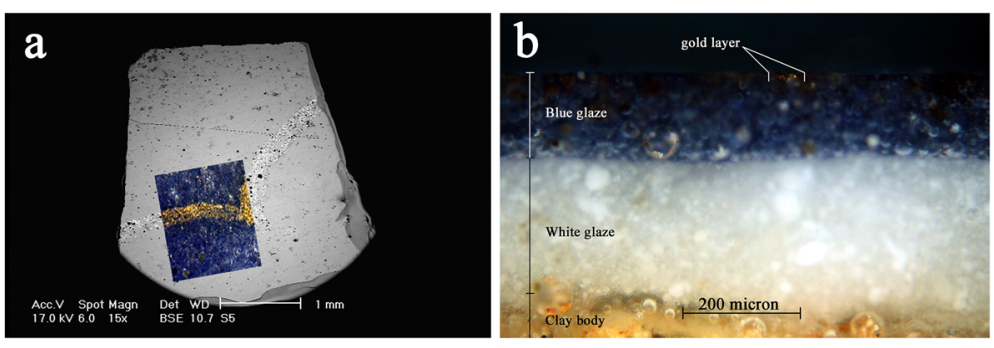

Figure $\mathbf{2}$ a) SEM back-scattered micrograph of the sample merged with the optical microscope image together with $\mathbf{b}$ ) the cross section of the gilded area. 
Table 1 The quantitative EPMA results on the blue and white glazes

\begin{tabular}{|c|c|c|c|c|c|c|c|c|c|c|c|c|c|}
\hline Elements & $A I$ & Si & $K$ & $M g$ & Co & $\mathrm{Na}$ & $\mathrm{Ca}$ & $\mathrm{Fe}$ & $\mathrm{Cu}$ & $\mathrm{Pb}$ & As & Sn & Actual total (wt\%) \\
\hline Blue & 2.81 & 63.99 & 4.29 & 0.37 & 0.51 & 9.43 & 1.84 & 1.95 & 0.04 & 0.95 & 0.06 & 0.02 & 86.26 \\
\hline White & 1.57 & 48.86 & 3.05 & 1.79 & $\mathrm{nd}^{*}$ & 7.91 & 4.03 & 0.58 & 0.07 & 20.86 & nd & 2.84 & 91.56 \\
\hline
\end{tabular}

*nd: not detected.

glaze and its thickness was very small (Figure $2 b$ ), it was not practically possible to remove any sample from the blue glaze without contaminating the sample with the white substrate glaze. Thus, the most appropriate technique, which could quantitatively measure boron from one hand and, on the other hand, did not require removing the blue glaze, was laser ablation-induced coupled plasma mass spectrometry (LA-ICP-MS), which we did not have access to.

\section{Gilding}

Optical microscopy and back-scattered electron micrographs revealed that the gilded layer was achieved by applying gold flakes on the blue glaze (Figure 3). As it is evident in Figure 3b, multiple bubbles were evolved where the gold flakes were placed on showing a reaction happened when gold flakes were fired on the blue glaze. Moreover, AFM observations proved that the gold flakes were immersed in the blue substrate glaze (Figure 4). The roughness of the blue glaze was markedly changed where the gold flakes were used (with $Z$ range, $R_{a}$ and RMS values of 281.8, 75.4 and $95.7 \mathrm{~nm}$ respectively) confirming that the gold flakes were fired on the blue glaze.

The $\mu$-XRF analysis showed that the golden layer was mainly composed of gold with which copper and silver were associated (Figure 5). Potassium, calcium, titanium, manganese, lead, cobalt and arsenic appeared in the $\mu$-XRF analysis of the golden layer are most certainly derived from the blue substrate glaze. One should note that the copper content appeared in the composition of the golden layer can also be associated with the blue glaze (see Table 1). Based on the $\mu$-XRF analysis, it could be hypothesised that the gold powder could not have been in a pure state and that is why the gold was used as powder instead of gold leaf. In other words, the lower malleability of the alloyed gold mainly resulted from silver and copper [19] was the reason of its use as gold flakes.

\section{Conclusion}

Although previous studies on the Persian gilded vitreous materials had showed the use of gold leaf pasted on the glassy surface by an adhesive, the current study revealed, for the first time, the application of gold flakes on a 19th century Persian haft rang tile adhered by firing gold flakes on a blue glaze. Moreover, the blue substrate glaze was revealed to be an alkali glaze coloured by cobalt. Further, the colouring agent of the blue glaze was probably supplied from the Qamsar cobalt ores. These cobalt ores, which were either cobaltite or erythrite, are probably fused with borax to be used in the composition of the blue glaze. Moreover, the white glaze showed to be a lead-alkali glaze opacified with tin oxide with a relatively high ratio of $\mathrm{Pb} / \mathrm{Sn}$ which is unusual in the context of Persian glaze technology.

\section{Methods}

\section{Samples}

AFM and $\mu$-XRF were performed on a small sample which was delicately removed with scalpel from a well-preserved haft rang tile placed in the south-eastern portico of the mausoleum. SEM observations were performed on the gold coated sample in order to prevent charging effect. For observing the cross section of the sample under PLM, another tiny sample was mounted in a 1:1 mixture of Araldite AW 8545-1:Hardener HW 8545-1 and was cut and polished to

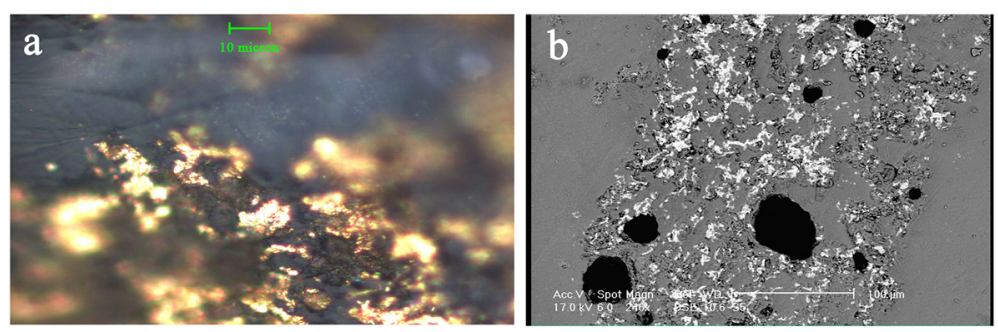

Figure $\mathbf{3}$ a) Optical microscope and $\mathbf{b}$ ) back-scattered SEM image of the gildings. 

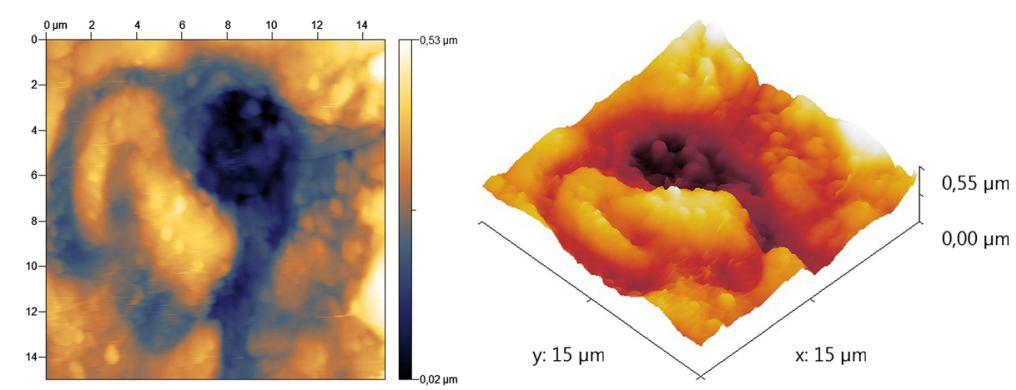

Figure 4 AFM images obtained from $15 \times 15 \mu$ m surface area of the gildings.

be observed under the PLM. The same sample was then coated with carbon to be analysed by EPMA.

\section{Optical microscopy}

The optical microscopy was performed with an Alltion BK-POLT (China) polarised light microscope (PLM). A Canon EOS Kiss $x 4$ digital camera was used to capture the photos under the plane light.

\section{$\mu$-XRF analysis}

The portable XRF was an ARTAX $^{\mathrm{m}} 200$ (Bruker AXS Microanalysis, Germany). Its X-ray tube was Mo placed at $6^{\circ}$ involving a $100 \mu \mathrm{m}$ beryllium window and a maximum voltage and current of $50 \mathrm{kV}$ and $1000 \mu \mathrm{A}$ respectively. The X-ray beam on the surface of the sample had $1 \mathrm{~mm}$ diameter and measurements were carried out in air for about $120 \mathrm{~s}$.

\section{SEM}

Scanning electron microscopy images were obtained with a Philips XL30 electron microscope in secondary and backscattered modes under about $10 \mathrm{~mm}$ of working distance and $17 \mathrm{kV}$ as an accelerating voltage.

\section{EPMA}

Electron microprobe analysis was performed with a JXA8230 field emission electron probe microanalyser in the wavelength-dispersive mode (WDS). The acceleration voltage, beam current and beam diameter were $15 \mathrm{kV}, 5 \mathrm{nA}$ and $10 \mu \mathrm{m}$ respectively. On-peak counting times were $10 \mathrm{~s}$ and counting times on the background on both sides of the peak were $5 \mathrm{~s}$. As standard for $\mathrm{Si}, \mathrm{Na}$ and $\mathrm{Al}$, we used wellcharacterised natural albite, galena for $\mathrm{Pb}$, olivine for $\mathrm{Fe}$ and $\mathrm{Mg}$, wollastonite for $\mathrm{Ca}$ and sanidine for $\mathrm{K}$, plus pure metals of $\mathrm{Co}$, $\mathrm{Sn}$ and $\mathrm{Cu}$.

\section{AFM}

The topography of the gilded zone was studied by a BrukerNanos atomic force microscope (Germany). AFM images were obtained by measurement of the interaction forces between the tip and the sample surface. The experiments were performed in air at room temperature and AFM images were processed with Image Plus 2.9 software.

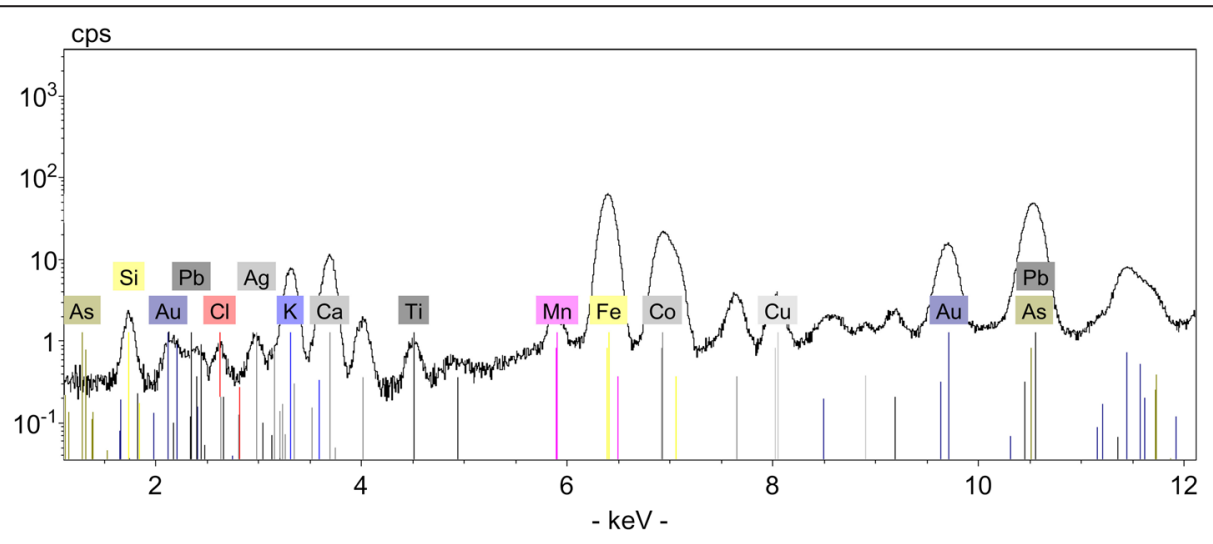

Figure $5 \mu-X R F$ spectrum of the gilded zone. 


\section{Competing interests}

The authors declare that they have no competing interests.

\section{Authors' contribution}

MM performed SEM observations and EPMA analyses while PH provided $\mu$-XRF and AFM observations. Both authors wrote, read and approved the final manuscript.

\section{Acknowledgements}

The supports of Carmela Vaccaro and Ralf Milke are cordially appreciated. Sajjad Mahmoudpour and Abdu'l Hamid Rezaei thanked for AFM and SEM observations respectively.

\section{Author details}

${ }^{1}$ Institute for Near Eastern Archaeology, Freie Universität Berlin, Hüttenweg 7, 14195 Berlin, Germany. ${ }^{2}$ Faculty of Conservation, Art University of Isfahan,

Hakim-Nezami St, P.O. Box 1744, Isfahan, Iran.

Received: 23 June 2014 Accepted: 27 March 2015

Published online: 16 April 2015

\section{References}

1. Darque-Ceretti $E_{1}$ Hélary D, Aucouturier M. An investigation of gold/ceramic and gold/glass interfaces. Gold Bull. 2002;35:118-29.

2. Pacheco C, Chapoulie R, Dooryhee E, Goudeau P. Gold leaf decoration on medieval Islamic glazed ceramics - in search of technological features with XRD. Z Kristallogr Suppl. 2007;26:317-23.

3. Gueit E, Darque-Ceretti E, Aucouturier M. Glass gilding process in medieval Syria and Egypt (13th-14th Century). J Archaeol Sci. 2010;37:1742-52.

4. Carboni S, Henderson J. Mamluk enamelled and gilded glass in the Museum of Islamic Art, Qatar. London: Islamic Art Society; 2003.

5. Mish Mast Nehi M, Chaman HR, Mortazavi M. Scanning electron microscopy and optical microscopic study of gilded tiles from Darb-i Imam Tomb in Isfahan, Iran. In: Meek A, Meeks N, Mongiatti A, Cartwright C, editors. Historical Technology, Materials and Conservation: SEM and Microanalysis. London: Archetype Publications; 2012. p. 179.

6. Osete-Cortina L, Doménech-Carbó MT, Doménech A, Yusá-Marco DJ, Ahmadi H. Multimethod analysis of Iranian Ilkhanate ceramics from the Takht-e Soleyman palace. Anal Bioanal Chem. 2010;397:319-29.

7. Allan JW. Abu'l Qasim's treatise on ceramics. Iran. 1973;11:111-20.

8. Ritter H, Ruska J, Winderlich R. Orientalische steinbücher und persische fayencetechnik. Abteilung Istanbul Des Archäologischen Institutes Des Deutschen Reiches. 1935;3:16-56.

9. Holakooei P, Tisato F, Vaccaro C, Petrucci FC. Haft rang or cuerda seca? Spectroscopic approaches to the study of overglaze polychrome tiles from seventeenth century Persia. J Archaeol Sci. 2014;41:447-60.

10. Vendrell M, Molera J, Tite MS. Optical properties of tin-opacified glazes. Archaeometry. 2000;42:325-40.

11. Ali Mohamed. On the manufacture of modern käshi earthenware tiles and vases in imitation of the ancient. In Leadless Decorative Tiles, Faience, and Mosaic. History, Materials, Manufacture and Use of Ornamental Flooring Tiles, Ceramic Mosaic, and Decorative Tiles and Faience. Recipes for Tilebodies, and for Leadless Glaze and Art-tile Enamels, Edited by Furnival WJ. Furnival WJ, Stone, Staffordshire; 1888:215.

12. Tite MS, Shortland A, Maniatis Y, Kavoussanaki D, Harris SA. The composition of the soda-rich and mixed alkali plant ashes used in the production of glass. J Archaeol Sci. 2006;33:1284-92.

13. Rehren T. A review of factors affecting the composition of early Egyptian glasses and faience: alkali and alkali earth oxides. J Archaeol Sci. 2008;35:1345-54

14. Stöllner T. Notes on mining archaeological structures at the cobalt mine of Qamsar. In: Stöllner T, Slotta R, Vatandoust A, editors. Persiens Antike Pracht. Buchum: DBM; 2004. p. 515.

15. Darrah JA. Connections and coincidences: three pigments. In: Arie W, Erma H, Marja P, editors. Historical Painting Techniques, Materials and Studio Practice. Marina del Rey: The Getty Conservation Institute; 1996. p. 70.

16. Rochechouart J. Souvenirs d'un voyage en Perse. Paris: Challamel Ainé; 1867.
17. Olmer ML-J. Rapport sur une Mission Scientifique en Perse, vol. XVI. Paris: Imprimerie Nationale; 1908.

18. Floor W. Traditional Crafts in Qajar Iran (1800-1925). California: Mazda Publishers; 2003.

19. Nutting J, Nuttall JL. The malleability of gold: an explanation of its unique mode of deformation. Gold Bull. 1977;10:2-8.

\section{Publish with ChemistryCentral and every scientist can read your work free of charge \\ "Open access provides opportunities to our colleagues in other parts of the globe, by allowing anyone to view the content free of charge." \\ W. Jeffery Hurst, The Hershey Company.}

- available free of charge to the entire scientific community

- peer reviewed and published immediately upon acceptance

- cited in PubMed and archived on PubMed Central

- yours - you keep the copyright

Submit your manuscript here:

http://www.chemistrycentral.com/manuscript/<smiles>c1ccccc1</smiles>

ChemistryCentral 